\title{
KENAIKAN TARIF DASAR LISTRIK DAN RESPON KEBIJAKAN UNTUK MEMINIMISASI DAMPAK NEGATIF TERHADAP PEREKONOMIAN INDONESIA
}

\author{
Tri Isdinarmiati ${ }^{1}$ dan Rina Oktaviani ${ }^{2}$ \\ ${ }^{1}$ Direktorat Neraca Pertambangan, Energi dan Konstruksi, \\ Badan Pusat Statistik (BPS), Jakarta \\ ${ }^{2}$ Departemen Ilmu Ekonomi, Fakultas Ekonomi dan Manajemen, \\ Institut Pertanian Bogor \\ Artikel diterima April 2012 \\ Artikel disetujui untuk dipublikasikan Juli 2012
}

\begin{abstract}
Electricity is one of the strategic commodities in Indonesia. The Increasing of electrical price (so called TDL stand for Tarif Dasar Listrik) administered by the government will be negative impact on Indonesian economic performance. Based on this research analysis, a rise of TDL will have negative impact on macro and sectoral economic performance. This study aims to analyze the effects of a rise of TDL and policy responses to minimize its negative impacts on Indonesian economic performance. The data which is used in this research areInput Output Table, Social Accounting Matrix (SAM) and SUSENAS data. Sources of data obtained from Board Central of Statistics. The analysis using Computable General Equilibrium (CGE) model is called INDOTDL CGE model. The simulation results show that a rise of TDL will have negative impact oneconomic growth, household consumption, export, employment and sectoral demand. This study also shows that an increase of efficiency in electricity sector by 10 percent is expected to decrease the electrical price. In addition, a rise of TDL which is followed by an increase of efficiency or decrease of value added tax (VAT) policy in all sector have positive impact on macro and sectoral economic performance on Indonesian. The most effective policy to economic improvementis to increase efficiency of electricity sector, so TDL doesn't need to be increased.
\end{abstract}

Keywords : TDL, CGE, Efficiency, VAT, Economic Performance

\begin{abstract}
ABSTRAK
Listrik merupakan salah satu komoditas strategis di Indonesia. Peningkatan harga listrik (disebut TDL, singkatan dari Tarif Dasar Listrik) yang diatur oleh pemerintah akan berdampak negatif pada kinerja ekonomi Indonesia. Berdasarkan analisis penelitian ini, kenaikan TDL akan berdampak negatif pada kinerja ekonomi makro dan sektoral. Penelitian ini bertujuan untuk menganalisis dampak kenaikan TDL dan respon-respon kebijakan guna meminimalkan dampak negatif pada kinerja ekonomi Indonesia. Data yang digunakan dalam penelitian ini adalah Tabel Input output, Social Accounting Matrix (SAM) dan data SUSENAS. Sumber-sumber data diperoleh dari Biro Pusat Statistik. Analisis yang menggunakan model Computable General Equilibrium (CGE) disebut model INDOTDL CGE. Hasil simulasi menunjukkan bahwa kenaikan TDL akan berdampak negatif terhadap pertumbuhan ekonomi, konsumsi rumah tangga, ekspor, lapangan kerja dan permintaan sektoral. Penelitian ini juga menunjukkan bahwa peningkatan efisiensi di sektor listrik sebesar 10 persen diharapkan dapat menurunkan harga listrik. Selain itu, kenaikan TDL yang diikuti oleh peningkatan efisiensi atau kebijakan penurunan pajak pertambahan nilai (PPN) di semua sektor memiliki dampak positif pada kinerja ekonomi makro dan sektoral di Indonesia. Kebijakan yang paling efektif dalam upaya peningkatan ekonomi adalah peningkatan efisiensi sektor listrik, sehingga TDL tidak perlu dinaikan.
\end{abstract}

Kata kunci: TDL, CGE, Efisiensi, PPN, Kinerja Ekonomi 


\section{Pendahuluan}

Listrik merupakan komoditi strategis yang digunakan hampir disemua sektor sehingga tarif dasar listrik (TDL) ditentukan pemerintah. Kenaikan harga BBM meningkatkan biaya operasional PLN, oleh karena itu Pemerintah harus memberikan subsidi agar tidak merugikan PLN. Pada tahun 2010 terjadi peningkatan subsidi listrik pemerintah ke PLN dari Rp 37,8 triliun (APBN 2010) menjadi Rp 55,1 triliun (APBN-P 2010). Peningkatan subsidi tersebut karena adanya perubahan asumsi ICP yang meningkat sebesar 15 USD/bbl dan peningkatan margin listrik PLN sebesar 3 persen. Walaupun subsidi listrik tahun 2010 meningkat sebesar Rp 17,3 triliun namun masih terdapat defisit subsidi listrik sebesar Rp 4,87 triliun, sehingga Pemerintah dengan persetujuan DPR harus menaikkan TDL. Kebijakan kenaikan TDL yang berlaku mulai 1 Juli 2010 hanya untuk pelanggan yang berdaya 1300 VA ke atas dengan tingkat kenaikan yang berbeda pada tiap kelompoknya. Kelompok rumahtangga mengalami kenaikan TDL sebesar 18 persen, sedangkan sektor industri kenaikannya dibatasi antara 6 - 15 persen.

Baru sebulan kenaikan TDL diputuskan, muncul wacana kenaikan TDL sebesar 15 persen pada tahun 2011 yang merupakan rencana pengurangan subsidi listrik secara bertahap, yaitu dari Rp 55,1 triliun pada 2010 menjadi Rp 41 triliun pada 2011. Rencana pemerintah kembali menaikkan TDL ini sempat menuai kontroversi dikalangan dunia usaha. Sehingga DPR memutuskan untuk menunda kenaikan TDL tahun 2011 dan memberi batasan kenaikan maksimal 18 persen pada sektor industri. Namun awal tahun 2011, PLN mencabut pembatasan kenaikan TDL di sektor industri sehingga kenaikan TDL sektor industri mencapai 20-30 persen. Kenaikan TDL selain bertujuan mengurangi beban subsidi listrik pada APBN juga mencegah subsidi yang salah sasaran, namun juga berdampak luas pada kinerja ekonomi makro dan sektoral di Indonesia.

Berdasarkan data dari PLN, kelompok pelanggan rumahtangga dan industri memiliki share yang besar dalam mengkonsumsi listrik yaitu masing-masing sebesar 40,83 persen dan 34,33 persen dari total penjualan listriknya. Oleh karena itu kenaikan TDL akan berpotensi menambah biaya produksi sektor ekonomi pengguna listrik, menurunkan konsumsi rumahtangga dan permintaan tenaga kerja. Selain itu, kenaikan TDL akan mendorong inflasi nasional yang berdampak pada turunannya pendapatan riil rumahtangga dan berpengaruh negatif terhadap kinerja ekonomi makro maupun sektoral, sejalan dengan penelitian-penelitian empiris sebelumnya (Rakhmanto 2010, Makmun dan Abdurahman 2003, Sahara 2003 dan Tribuana N 2000). Sejalan dengan latar belakang di atas, tulisan ini akan difokuskan pemba-hasannya pada bagaimana dampak kenaikan tarif dasar listrik khususnya terhadap rumah tangga dan sektor industri serta respon kebijakan untuk meminimisasi dampak negatif terhadap perekonomian Indonesia.

\section{Metode Penelitian}

Penelitian ini mengkaji kenaikan tarif dasar listrik dan respon kebijakan untuk meminimisasi dampak negatif terhadap perekonomian Indonesia. Data utama yang digunakan dalam penelitian ini adalah Tabel I-O tahun 2008 dan Tabel SNSE tahun 2008 yang bersumber dari BPS. Data dasar disusun dengan melakukan agregasi dan disagregasi pada Tabel I-O dan Tabel SNSE menjadi 21 sektor. Analisis penelitian menggunakan model CGE INDOMINI (Oktaviani, 2008) yang dikolaborasi dengan model CGE WAYANG (Wittwar, 1999) dan selanjutnya disebut model $\boldsymbol{C} \boldsymbol{G E}$ INDOTDL. Sistem persamaan yang digunakan dalam model ini meliputi 15 
blok sesuai dengan model INDOMINI. Hal yang berbeda pada model CGE INDOTDL dengan model INDOMINI adalah rumahtangga dipisah menjadi 2 yaitu rumahtangga berdaya listrik 450VA-900VA (rumahtangga bawah) dan rumahtangga berdaya $1300 \mathrm{VA}$ keatas (rumahtangga atas).

Rumahtangga diasumsikan memaksimumkan utilitas (kepuasan) dalam memilih sekumpulan barang yang optimal untuk dikonsumsi dengan kendala anggaran. Kendala anggaran yang dihadapi pada tiap kelompok rumahtangga adalah nilai total pembelian tiap kelompok rumahtangga merupakan peubah eksogen bagi rumahtangga. Model CGE INDOTDL ini tidak menghubungkan antara pengeluaran rumahtangga, artinya tidak ada keputusanmenabung/mengkonsumsi.

Kesediaan anggaran untuk dikonsumsi pada tiap kelompok rumahtangga dinyatakan dalam bentuk nominal W3TOT_hh. Kepuasan diasumsikan menggunakan fungsi kepuasan berjenjang. Model INDOTDL membagi rumahtangga menjadi 2 sehingga persamaan permintaan rumahtangga di model CGE INDOMINI disesuaikan menjadi:
$X_{-} S(c, H H)=\frac{a_{c} x W 3 T O T_{-} H H}{P_{-} S(c, H H)} ;(c \in C O M)(u \in H H)$

$X 3 T O T \times P 3 T O T=\sum_{u \in H H} \sum_{c \in C O M} X_{-} S(c, H H) \times P_{-} S(c, H H)$

Dimana :

\begin{tabular}{|c|c|}
\hline X_S(c,HH) & $\begin{aligned}= & \text { jumlah komoditi yang } \\
& \text { dikonsumsi } \\
& \text { kelompok rumahtangga }\end{aligned}$ \\
\hline P_S(c,HH) & $\begin{aligned}= & \text { harga komoditi yang } \\
& \text { dikonsumsi tiap } \\
& \text { kelompok rumahtangga. }\end{aligned}$ \\
\hline W3TOT_HH & $\begin{array}{l}=\text { anggaran yang tersedia } \\
\text { untuk konsumsi } \\
\text { perkelompok } \\
\text { rumahtangga. }\end{array}$ \\
\hline X3ТОT & $=$ konsumsi riil total \\
\hline P3TOT & $=$ harga konsumen. \\
\hline$a_{c}$ & $\begin{aligned}= & \text { pangsa } \\
& \text { rumahtangga } \\
& \text { komoditi } \mathrm{c} .\end{aligned}$ \\
\hline $\mathrm{HH}$ & $\begin{array}{l}=\text { rumahtangga bawal } \\
\text { rumahtangga atas }\end{array}$ \\
\hline
\end{tabular}
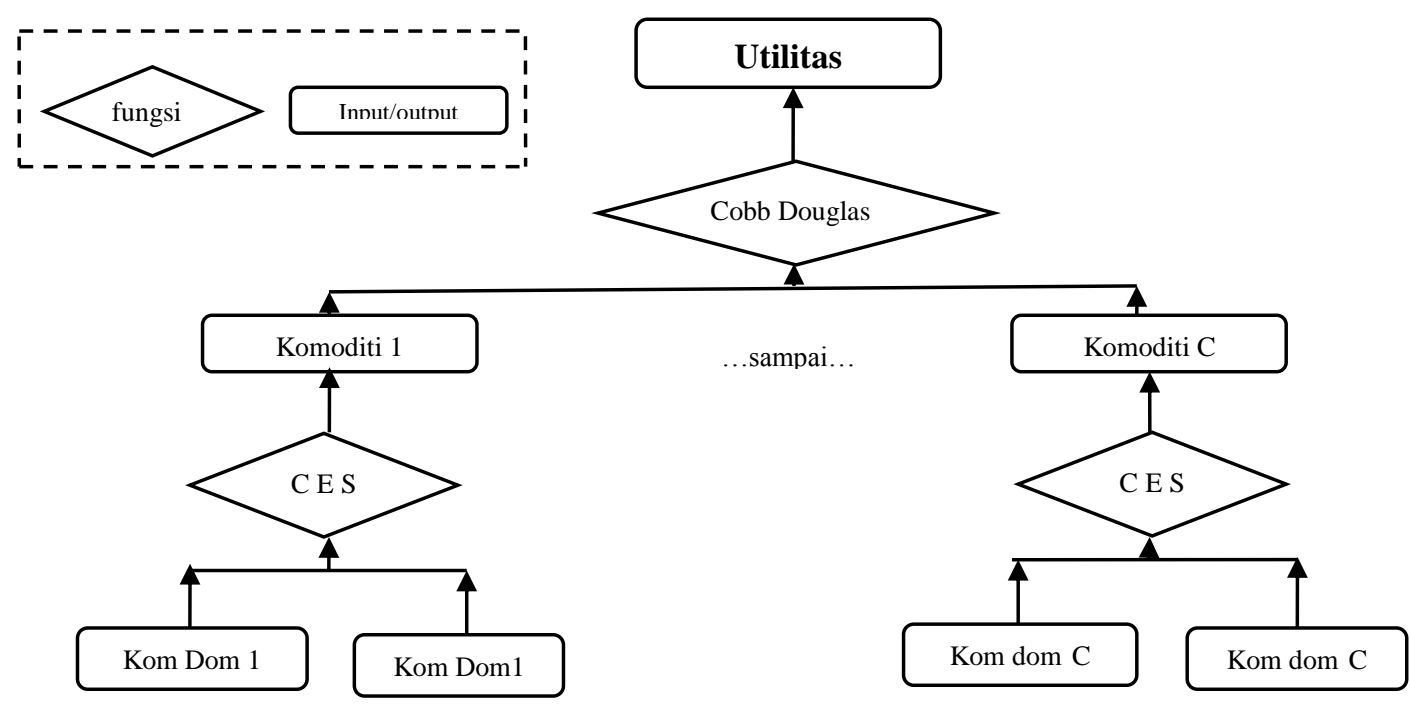

Sumber: Horridge, 2001

Gambar 1. Struktur Permintaan Konsumen (Rumahtangga) Berjenjang 
Data yang dimasukkan ke dalam model CGE INDOTDL adalah tabel I-O tahun 2008 klasifikasi 66 sektor yang dipadukan dengan data lain dan diolah sedemikian rupa sesuai tujuan penelitian. Penyusunan data diawali dengan melakukan pemetaan kode I-O dengan kode SNSE kemudian dilakukan disagregasi dan agregasi sektor sesuai tujuan penelitian. Disagregasi dilakukan pada sektor listrik, gas kota dan air (LGA) menjadi 4 sektor yang terpisah dengan menggunakan data I-O UKM 2003 dan neraca produksi LGA. Pada tabel I-O sektor listrik juga dipisah menjadi 2 yaitu listrik 900 kebawah dan listrik 1300 keatas. Dissagregasi juga dilakukan pada tabel SNSE tahun 2008 dari 24 sektor produksi yang ada menjadi 27 sektor produksi, dari hasil disagregasi sektor pada tiap tabel kemudian dilakukan agregasi menjadi 21 sektor penelitian.

Tabel 1. Set Matriks pada Model CGE INDOTDL

\begin{tabular}{ll}
\hline \multicolumn{1}{c}{ Set } & \multicolumn{1}{c}{ Keterangan } \\
\hline COM (c) / IND(i) & (1) Pertanian, (2) Pertambangan dan penggalian (3) Industri makanan, \\
& minuman dan tembakau (4) Industri tekstil, pakaian dan kulit dan \\
& pemintalan, (5) Industri Bambu, kayu, rotan \& barang dr kayu (6) Industri \\
& kertas, barang dari kertas dan karton, (7) Industri Kimia,Pupuk,dan hasil \\
& kilang, (8) Industri barang karet, plastik \& mineral bukan logam, (9) \\
& Industri semen, (10) Industri logam dasar besi dan baja \& bukan besi, (11) \\
& Industri barang dari logam, (12) Industri mesin, alat-alat, perlengkapan listrik \\
& dan alat pengangkutan dan perbaikannya, (13) Industri lainnya, (14) Listrik 900 \\
& VA kebawah, (15) Listrik 1300 VA keatas (16) Gas kota \& air, (17) Bangunan, \\
& (18) Perdagangan, hotel dan restoran, (19) Pengangkutan dan komunikasi, \\
& (20) Lembaga keuangan, real estat dan jasa perusahaan dan (21) Jasa \\
SRC (i) & (1) domestik dan (2) impor \\
HH (h) & (1) rumah tangga bawah (2) rumah tangga atas \\
Faktor Produksi & (1) tenaga kerja dan (2) modal (capital) \\
Pengguna & Penggunan antara dan pengguna akhir (final User) \\
Pengguna akhir & (1) Investasi dan stok, (2) rumahtangga bawah (3) rumahtangga atas (4) \\
& Ekspor (5) pemerintah \\
\hline
\end{tabular}

Analisis jangka waktu yang digunakan dalam penelitian ini adalah jangka pendek (short run) dengan asumsi stok kapital dan upah riil tetap dan jangka panjang (long run) dengan asumsi telah terjadi penyesuaian pada stok kapital dan upah riil akibat adanya guncangan dalam perekonomian. Banyaknya persamaan yang terdapat dalam model CGE dan adanya keterkaitan peubah dan persamaan satu dengan lainnya memungkinkan terdapat peubah yang merupakan endogen dan sekaligus dapat pula menjadi eksogen. Seluruh peubah yang masuk katagori eksogen didefinisikan dalam file closure tersendiri di dalam software Gempack. Closure jangka pendek dan jangka panjang yang digunakan pada model IndoTDL ditunjukkan pada Tabel 2 . 
Tabel 2. Closure Jangka Pendek pada Model INDOTDL

\begin{tabular}{|c|c|c|c|c|}
\hline \multirow[t]{2}{*}{ No. } & \multicolumn{2}{|c|}{ Peubah Variabel } & \multirow[t]{2}{*}{ Size } & \multirow[t]{2}{*}{ Keterangan } \\
\hline & Jangka Pendek & Jangka Panjang & & \\
\hline 1 & phi & phi & 1 & Nilai tukar Rp/\$US \\
\hline 2 & x_s(COM,” InvStock") & x_s(COM," InvStock") & $\mathrm{COM}$ & $\begin{array}{l}\text { Permintaan } \\
\text { investasi }\end{array}$ \\
\hline 3 & x_s(COM," GovGE") & x_s(COM," GovGE") & $\mathrm{COM}$ & $\begin{array}{l}\text { Permintaan } \\
\text { pemerintah }\end{array}$ \\
\hline 4 & x1cap & - & IND & $\begin{array}{l}\text { Stok modal saat ini } \\
\text { Tingkat }\end{array}$ \\
\hline 5 & - & Gret & IND & $\begin{array}{l}\text { pengembalian } \\
\text { modal }\end{array}$ \\
\hline 6 & realwage & - & 1 & Upah riil \\
\hline 7 & - & employ & 1 & $\begin{array}{l}\text { Penyerapan tenaga } \\
\text { kerja }\end{array}$ \\
\hline 8 & $\begin{array}{l}\text { f3tax(COM, } \\
\text { "HouseHB") }\end{array}$ & $\begin{array}{l}\text { f3tax }(\mathrm{COM}, \\
\text { "HouseHB") }\end{array}$ & $\mathrm{COM}$ & $\begin{array}{l}\text { Shifter pajak } \\
\text { rumah tangga } \\
\text { bawah }\end{array}$ \\
\hline 9 & $\begin{array}{l}\text { f3tax }(\mathrm{COM}, \\
\text { "HouseHA") }\end{array}$ & $\begin{array}{l}\text { f3tax }(\mathrm{COM}, \\
\text { "HouseHA") }\end{array}$ & $\mathrm{COM}$ & $\begin{array}{l}\text { Shifter pajak } \\
\text { rumah tangga atas }\end{array}$ \\
\hline 10 & alprim & a1prim & IND & $\begin{array}{l}\text { Perubahan teknis } \\
\text { penggunaan } \\
\text { factor prod }\end{array}$ \\
\hline 11 & pworld & pworld & $\mathrm{COM}$ & Harga dunia (\$US) \\
\hline 12 & $\mathrm{f} 4 \mathrm{q}$ & $\mathrm{f} 4 \mathrm{q}$ & $\mathrm{COM}$ & $\begin{array}{l}\text { Shifter permintaan } \\
\text { ekspor }\end{array}$ \\
\hline 13 & Delmtxrate & Delmtxrate & $\mathrm{COM}$ & $\begin{array}{l}\text { Tingkat pajak } \\
\text { impor }\end{array}$ \\
\hline 14 & Delptxrate & Delptxrate & $\mathrm{COM}$ & $\begin{array}{l}\text { Tingkat pajak } \\
\text { produksi }\end{array}$ \\
\hline
\end{tabular}

Untuk melihat dampak kenaikan TDL dan respon kebijakan untuk meminimisasi dampak negatif terhadap perekonomian Indonesia dilakukan analisis dengan 4 skenario. Dimana skenario 1 adalah gonjangan harga listrik berdaya 1300 VA ke atas pada sektor industri sebesar 30 persen dan rumahtangga sebesar 18 persen. Skenario 2 adalah gonjangan jika ada peningkatan efisiensi produksi di sektor listrik sebesar 10 persen. Dan skenario 3 merupakan simulasi pada skenario 1 yang diikuti peningkatan efisiensi pada seluruh sektor ekonomi sebesar 1 persen. Sedangkan skenario 4 adalah simulasi dimana skenario 1 jika diikuti kebijakan penurunan PPN pada seluruh sektor sebesar 1 persen.

\section{Hasil dan Pembahasan}

\subsection{Dampak Kenaikan TDL Terhadap perekonomian Indonesia.}

Hasil simulasi kenaikan TDL pada sektor industri sebesar 30 persen dan rumahtangga sebesar 18 persen berdampak negatif terhadap PDB riil yaitu turun sebesar 0,27 persen pada jangka pendek. Pada jangka panjang penurunannya PDB riil jauh lebih besar yaitu sebesar 1,56 persen karena adanya penurunan ekspor hingga turun sebesar 3,28 persen. Hal ini terjadi karena kenaikan harga ekspor sebesar 0,25 persen yang mendorong kenaikan harga output di pasar internasional sehingga daya saing produk ekspor Indonesia di luar negeri menurun. 
Sama halnya dengan volume ekspor, pada jangka pendek maupun jangka panjang kenaikan TDL berdampak pada penurunan volume impor masingmasing sebesar 0,21 persen dan 0,54 persen. Penurunan impor tersebut cenderung pada produk antara untuk produksi yang bahan bakunya sebagian besar masih tergantung pada impor. Pergeseran kurva agregrat penawaran ke kiri atas juga akan menyebabkan pergeseran ke bawah kurva permintaaan tenaga kerja. Pada jangka pendek, penurunan tenaga kerja yang terjadi adalah sebesar 0,89 persen. Hal ini menunjukan bahwa kebijakan yang dilakukan pemerintah tersebut akan semakin memperburuk kondisi pasar tenaga kerja di Indonesia.

Kebijakan kenaikan TDL akan mendorong inflasi sebesar 0,09 persen pada jangka pendek dan 0,24 persen pada jangka panjang. Sejalan dengan inflasi nasional tingkat upah nominal tenaga kerja meningkat sebesar 0,09 persen pada jangka pendek. Sebaliknya pada jangka panjang upah nominal tenaga kerjanya mengalami penurunan sebesar 0,67 persen. Hal ini terjadi karena permintaan kapital dijangka panjang mengalami penyesuaian sehingga produsen bisa bebas menentukan kapital yang akan digunakan sehingga dapat menekan upah riil tenaga kerjanya.

Tabel 3. Dampak Kenaikan TDL terhadap Peubah-peubah Ekonomi Makro di Indonesia.

\begin{tabular}{lcc}
\multicolumn{1}{c}{ DESKRIPSI } & \multicolumn{2}{c}{ DAMPAK (\%) } \\
\cline { 2 - 3 } Peubah Ekonomi Makro & SR & LR \\
\hline Neraca perdagangan/PDB (delB) & 0,00 & $-0,01$ \\
Tenaga kerja (employ) & $-0,89$ & 0,00 \\
Indeks deflator PDB sisi & 0,07 & 0,25 \\
pengeluaran (pOgdpexp) & 0,09 & $-0,67$ \\
Upah nominal (p1lab) & 0,06 & 0,15 \\
Indeks harga investasi (p2tot) & 0,09 & 0,24 \\
Indeks harga konsumen (p3tot) & 0,02 & 0,25 \\
Indeks harga ekspor (p4tot) & 0,00 & $-0,91$ \\
Upah riil (realwage) & $-0,21$ & $-0,54$ \\
Indeks volume impor (xOcif_c) & $-0,27$ & $-1,56$ \\
PDB riil penggunaan (xOgdpexp) & $-0,44$ & $-1,29$ \\
Konsumsi RT (x3tot) & $-0,24$ & $-3,28$ \\
\hline Indeks volume ekspor (x4tot) & & \\
\hline
\end{tabular}

Keterangan :

$\mathrm{SR}=$ jangka pendek (short-run)

$\mathrm{LR}=$ jangka panjang (long-run)

Kenaikan harga investasi pada jangka panjang mencapai 0,15 persen lebih besar dari jangka pendek yang hanya naik sebesar 0,06 persen. Kenaikan harga investasi ini menyebabkan investor kurang tertarik menanamkan modalnya. Padahal penanaman modal yang dilakukan oleh investor menjadi stimulus bagi sektor produksi untuk meningkatkan produksinya. Hasil analisis di atas menunjukan dampak negatif kenaikan TDL terhadap ekonomi makro di Indonesia jauh lebih besar untuk jangka panjang jika tidak diikuti kebijakan lain. 
Sektor industri merupakan sektor yang paling rentan terkena dampak kenaikan TDL dimana penurunan output dalam jangka pendek berkisar antara 0,10 persen (industri kimia) sampai dengan 0,66 persen (industri tekstil, pakaian jadi, kulit dan industri logam dasar besi, baja dan bukan besi). Sedangkan pada jangka panjang sektor industri mengalami penurunan output dengan kisaran yaitu
0,34 persen (industri semen) sampai dengan 9,69 persen (industri logam dasar besi, baja, dan bukan besi). Penurunan yang cukup besar di sektor industri logam dasar besi, baja dan bukan besi dalam jangka panjang tersebut disebabkan karena pengaruh penurunan investasi secara agregat sebagai dampak dari kenaikan harga investasi padahal sektor ini termasuk sektor yang padat modal.

Tabel 4. Dampak Kenaikan TDL terhadap Output, Tingkat Harga, dan Permintaan Tenaga Kerja

\begin{tabular}{|c|c|c|c|c|c|c|}
\hline \multirow{2}{*}{ SEKTOR } & \multicolumn{2}{|c|}{ OUTPUT (\%) } & \multicolumn{2}{|c|}{ HARGA OUTPUT (\%) } & \multicolumn{2}{|c|}{$\begin{array}{c}\text { PERMINTAAN } \\
\text { TENAGA KERJA (\%) }\end{array}$} \\
\hline & SR & LR & SR & LR & SR & LR \\
\hline Pertanian & $-0,31$ & $-1,23$ & 0,00 & $-0,01$ & $-1,39$ & 5,91 \\
\hline Tambangali & $-0,03$ & $-1,55$ & $-0,02$ & 0,05 & $-0,23$ & $-0,51$ \\
\hline IndMakMin & $-0,35$ & $-1,41$ & 0,01 & 0,05 & $-1,18$ & 1,19 \\
\hline IndTekstPak & $-0,66$ & $-6,69$ & 0,05 & 0,67 & $-2,00$ & $-6,17$ \\
\hline IndBambuKy & $-0,13$ & $-1,02$ & 0,01 & 0,32 & $-0,47$ & $-0,73$ \\
\hline IndKertas & $-0,28$ & $-2,27$ & 0,03 & 0,59 & $-0,92$ & $-1,98$ \\
\hline IndKimia & $-0,10$ & $-1,73$ & $-0,02$ & 0,05 & $-0,42$ & $-0,79$ \\
\hline IndKrtPIstk & $-0,43$ & $-2,11$ & 0,05 & 0,28 & $-1,20$ & $-1,60$ \\
\hline IndSemen & $-0,18$ & $-0,34$ & 1,41 & 1,71 & $-0,60$ & $-0,05$ \\
\hline IndLgmDsr & $-0,66$ & $-9,69$ & 0,05 & 0,90 & $-3,75$ & $-9,38$ \\
\hline IndBrgLgm & $-0,28$ & $-0,90$ & 0,15 & 0,37 & $-0,78$ & $-0,38$ \\
\hline IndMesin & $-0,32$ & $-2,55$ & 0,02 & 0,30 & $-1,03$ & $-1,99$ \\
\hline Indlainnya & $-0,64$ & $-3,19$ & 0,14 & 0,75 & $-1,54$ & $-2,96$ \\
\hline Listrik900 & $-0,06$ & $-1,14$ & $-0,20$ & $-0,01$ & $-0,25$ & $-0,84$ \\
\hline Listrik1300 & $-2,13$ & $-4,09$ & 30,26 & 30,10 & $-7,88$ & $-3,80$ \\
\hline Gasair & $-0,40$ & $-1,70$ & 0,09 & 0,83 & $-1,58$ & $-1,09$ \\
\hline Bangunan & $-0,02$ & $-0,12$ & 0,06 & 0,13 & $-0,06$ & 0,14 \\
\hline PerdagHR & $-0,34$ & $-1,58$ & 0,05 & 0,42 & $-1,08$ & $-1,02$ \\
\hline Angkom & $-0,48$ & $-2,11$ & 0,04 & 0,20 & $-1,51$ & $-0,78$ \\
\hline KeuJspersh & $-0,13$ & $-1,49$ & $-0,19$ & 0,16 & $-0,57$ & $-0,98$ \\
\hline JasaLain & $-0,32$ & $-0,68$ & 0,18 & 0,04 & $-0,47$ & $-0,28$ \\
\hline
\end{tabular}

Keterangan :

$\mathrm{SR}=$ jangka pendek (short-run)

$\mathrm{LR}=$ jangka panjang (long-run)

Kenaikan TDL mengakibatkan kenaikan biaya produksi, yang pada akhirnya akan meningkatkan biaya output. Sektor industri mengalami kenaikan harga output berkisar antara 0,01 persen (industri bambu, kayu dan rotan) hingga 1,41 persen (industri semen) pada jangka pendek. Tingginya kenaikan harga output semen, karena kebutuhan listrik untuk produksinya semen sangat tinggi yaitu mencapai 10,01 persen dari total biaya produksinya. Pada jangka panjang hampir seluruh sektor ekonomi mengalami kenaikan harga, kecuali sektor pertanian turun 0,01 persen 
Kebijakan kenaikan TDL juga mengakibatkan penurunan permintaan tenaga kerja sektor industri yang berkisar antara 0,47 persen (industri bambu, kayu dan rotan) sampai 3,75 persen (industri logam dasar besi, baja dan bukan besi) pada jangka pendek. Pada jangka panjang, sektor industri logam dasar besi, baja dan bukan besi merupakan sektor yang mengalami penurunan penyerapan tenaga kerja terbesar yaitu 9,38 persen. Sebaliknya pada jangka panjang, industri makanan, minuman dan tembakau terjadi kenaikan penyerapan tenaga kerja akibat kenaikan TDL. Hal ini bisa terjadi karena pada jangka panjang stok kapital dan upah riil mengalami penyesuaian sehingga turunnya upah riil dan meningkatnya harga investasi mendorong permintaan tenaga kerja.
Kenaikan TDL secara agregat akan berdampak negatif pada total pendapatan dan total konsumsi pada tiap kelompok rumahtangga baik pada jangka pendek maupun panjang seperti pada Tabel 5 . Dampak kenaikan TDL akan direspon rumahtangga melalui penurunan konsumsi yang lebih besar pada rumahtangga atas (berdaya 1300 VA ke atas). Rumahtangga bawah ( berdaya 900 VA kebawah) juga mengalami penurunan konsumsi yang akan semakin besar dijangka panjang. Penurunan konsumsi rumahtangga tersebut selain akibat langsung dan tak langsung kenaikan TDL yang menyebabkan kenaikan harga output terutama industri. Kebijakan kenaikan TDL menyebabkan penurunan total pendapatan maupun konsumsi rumahtangga atas cenderung lebih besar daripada rumahtangga bawah.

Tabel 5. Dampak Kenaikan TDL terhadap Total Pendapatan dan Konsumsi Rumahtangga

\begin{tabular}{ccccc}
\hline \multirow{2}{*}{ KELOMPOK } & \multicolumn{2}{c}{ TOTAL PENDAPATAN } & $(\%)$ & \multicolumn{2}{c}{ KONSUMSI RIIL (\%) } \\
\cline { 2 - 5 } & SR & LR & SR & LR \\
\hline Rumahtangga Bawah & $-0,14$ & $-0,84$ & $-0,16$ & $-1,01$ \\
Rumahtangga Atas & $-1,63$ & $-2,32$ & $-2,09$ & $-2,93$ \\
\hline
\end{tabular}

Keterangan :

$\mathrm{SR}=$ jangka pendek (short-run)

$\mathrm{LR}=$ jangka panjang (long-run)

\subsection{Kebijakan untuk Meminimisasi Dampak Negatif Kenaikan TDL}

\subsubsection{Peningkatan Efisiensi di Sektor Listrik}

Hasil simulasi dengan meningkatkan efisiensi produksi pada sektor listrik sebesar 10 persen berdampak positif terhadap perekonomian Indonesia baik pada jangka panjang maupun jangka pendek masing-masing PDB riil meningkat sebesar 0,34 persen dan 0,57 persen. Peningkatan PDB riil ini didorong peningkatan output pada seluruh sektor ekonomi sehingga permintaan tenaga kerja meningkat hingga 0,64 persen. Peningkatan permintaan tenaga kerja ini akan menyebabkan total pendapatan dan total konsumsi rumahtangga meningkat.

Efisiensi di sektor listrik pada jangka panjang berdampak semakin besar pada peningkatan PDB riilnya karena peningkatan volume ekspornya sebesar 0,82 persen karena adanya penurunan harga ekspor sehingga mampu bersaing harga di pasar internasional. Penurunan harga investasi baik di jangka pendek maupun panjang akan menarik investor untuk menanamkan modal pada sektor ekonomi sehingga roda perekonomian akan bergerak dengan upah riil yang meningkat hingga 0,29 
persen pada jangka panjang. Selain itu efisiensi di sektor listrik sebesar 10 persen mampu menurunkan harga listrik sebesar 24,97 persen sehingga subsidi listrik bisa dibatasi dan tidak membebani APBN. Turunnya harga listrik mampu menekan biaya produksi sektor pengguna listrik sehingga harga output turun dan mendorong permintaan sektoral sehingga output sektoral meningkat yang akan diikuti peningkatan penyerapan tenaga kerja sektoral.

Tabel 6. Dampak Peningkatan Efisiensi di Sektor Listrik terhadap Peubah-peubah Ekonomi Makro di Indonesia

\begin{tabular}{lcc}
\hline \multicolumn{1}{c}{ DESKRIPSI Peubah Ekonomi Makro } & \multicolumn{2}{c}{ DAMPAK (\%) } \\
\cline { 2 - 3 } \multicolumn{1}{c}{ SR } & LR \\
\hline Neraca perdagangan/PDB (delB) & 0,00 & 0,00 \\
Tenaga kerja (employ) & 0,64 & 0,00 \\
Indeks deflator PDB sisi pengeluaran & $-0,10$ & $-0,10$ \\
(p0gdpexp) & $-0,13$ & 0,17 \\
Upah nominal (p1lab) & $-0,04$ & $-0,03$ \\
Indeks harga investasi (p2tot) & $-0,13$ & $-0,11$ \\
Indeks harga konsumen (p3tot) & 0,01 & $-0,06$ \\
Indeks harga ekspor (p4tot) & 0,00 & 0,29 \\
Upah riil (realwage) & 0,42 & 0,30 \\
Indeks volume impor (x0cif_c) & 0,34 & 0,57 \\
PDB riil penggunaan (x0gdpexp) & 0,79 & 0,68 \\
Konsumsi RT (x3tot) & $-0,10$ & 0,82 \\
\hline Indeks volume ekspor (x4tot) &
\end{tabular}

Keterangan :

$\mathrm{SR}=$ jangka pendek (short-run)

$\mathrm{LR}=$ jangka panjang (long-run)

Pada jangka pendek maupun panjang, kenaikan TDL yang diikuti efisiensi di sektor listrik berdampak positif pada total pendapatan dan total konsumsi di setiap kelompok rumahtangga. Turunnya harga listrik akan mendorong aktivitas produksi sehingga mampu meningkatkan pendapatan masyarakat dan berdampak pada peningkatan konsumsi rumahtangga. Peningkatan total konsumsi rumahtangga bawah maupun rumahtangga atas masingmasing sebesar 0,66 persen dan 1,58 persen pada jangka pendek. Pada jangka panjang peningkatan total konsumsi rumahtangga atas semakin kecil yaitu meningkat hanya 0,65 persen

Tabel 7. Dampak Peningkatan Efisiensi di Sektor Listrik terhadap Total Pendapatan dan Konsumsi Rumahtangga

\begin{tabular}{ccccc}
\hline \multirow{2}{*}{ KELOMPOK } & \multicolumn{2}{c}{ TOTAL PENDAPATAN } & (\%) & \multicolumn{2}{c}{ KONSUMSI RIIL (\%) } \\
\cline { 2 - 5 } & SR & LR & SR & LR \\
\hline Rumahtangga Bawah & 0,55 & 0,57 & 0,66 & 0,69 \\
Rumahtangga Atas & 1,31 & 0,54 & 1,58 & 0,65 \\
\hline
\end{tabular}

Keterangan :

$\mathrm{SR}=$ jangka pendek (short-run)

$\mathrm{LR}=$ jangka panjang (long-run) 


\subsubsection{Kenaikan TDL diikuti Peningkatan Efisiensi di Seluruh Sektor}

Hasil simulasi dampak kenaikan TDL yang diikuti efisiensi produksi sebesar 1 persen disemua sektor ekonomi yang ditujukan untuk mengurangi dampak kenaikan TDL berdampak positif dalam meningkatkan PDB riil sebesar 1,55 persen pada jangka pendek. Pada jangka panjang efisiensi diseluruh sektor berdampak lebih baik yaitu meningkatkan PDB riilnya hingga 5,12 persen. Peningkatan PDB riil tersebut didorong adanya peningkatan output hampir disemua sektor ekonomi akibat adanya efisiensi produksi di seluruh sektor. Kenaikan PDB riil pada jangka pendek didorong oleh lonjakan ekspor riil dan peningkatan total konsumsi rumahtangga masing-masing sebesar 1,47 persen dan 1,99 persen. Pada jangka panjang peningkatan PDB riil juga karena lonjakan pada volume ekspor yang mencapai 5,62 persen dan kenaikan total konsumsi rumahtangga yang meningkat hingga 6,31 persen.

Kenaikan TDL yang diikuti efisiensi produksi diseluruh sektor, dalam jangka pendek menyebabkan peningkatan permintaan tenaga kerja sebesar 1,72 persen. Hal ini memberi indikasi bahwa kebijakan efisiensi produksi diseluruh sektor mampu menghindari kondisi pasar tenaga kerja di Indonesia yang semakin menurun akibat kenaikan TDL. Selain itu, pada jangka pendek kebijakan efisiensi produksi yang dilakukan semua sektor ekonomi mampu merendam inflasi akibat kenaikan TDL. Sedangkan pada jangka panjang terjadi penurunan indeks harga konsumen sebesar 0,14 persen akibat penurunan harga outputnya di seluruh sektor.

Tabel 8. Dampak Kenaikan TDL Diikuti Peningkatan Efisiensi di Seluruh Sektor terhadap Peubah-peubah Ekonomi Makro di Indonesia

\begin{tabular}{lcc}
\multicolumn{1}{c}{ DESKRIPSI } & \multicolumn{2}{c}{ DAMPAK (\%) } \\
\cline { 2 - 3 } Peubah Ekonomi Makro & SR & LR \\
\hline Neraca perdagangan/PDB (delB) & 0,00 & 0,01 \\
Tenaga kerja (employ) & 1,72 & 0,00 \\
Indeks deflator PDB sisi pengeluaran & $-0,36$ & $-0,20$ \\
(pOgdpexp) & 0,01 & 1,82 \\
Upah nominal (p1lab) & $-1,05$ & $-0,15$ \\
Indeks harga investasi (p2tot) & 0,01 & $-0,14$ \\
Indeks harga konsumen (p3tot) & $-0,06$ & $-0,25$ \\
Indeks harga ekspor (p4tot) & 0,00 & 1,96 \\
Upah riil (realwage) & 0,40 & 1,34 \\
Indeks volume impor (xOcif_c) & 1,55 & 5,12 \\
PDB riil penggunaan (xOgdpexp) & 1,99 & 6,31 \\
Konsumsi RT (x3tot) & 1,47 & 5,62 \\
Indeks volume ekspor (x4tot) & & \\
\hline
\end{tabular}

Keterangan :

$\mathrm{SR}=$ jangka pendek (short-run)

$\mathrm{LR}=$ jangka panjang (long-run) 
Kenaikan TDL yang diikuti efisiensi di seluruh sektor ekonomi ternyata berdampak positif pada total pendapatan dan total konsumsi di setiap kelompok rumahtangga baik pada jangka pendek maupun panjang. Pada jangka pendek, peningkatan konsumsi rumahtangga terjadi pada rumahtangga bawah maupun rumahtangga atas masing-masing sebesar
2,29 persen dan 0,27 persen. Pada jangka panjang peningkatan total konsumsi rumahtangga semakin besar sejalan dengan peningkatan total pendapatannya. Hasil penelitian menunjukan kebijakan kenaikan TDL yang diikuti efisiensi produksi di seluruh sektor lebih dinikmati rumahtangga bawah karena tidak terkena dampak langsung kenaikan TDL.

Tabel 9. Dampak Kenaikan TDL diikuti Peningkatan Efisiensi di Seluruh Sektor terhadap Total Pendapatan dan Konsumsi Rumahtangga

\begin{tabular}{cccccc}
\hline \multirow{2}{*}{ KELOMPOK } & \multicolumn{2}{c}{ TOTAL PENDAPATAN } & $(\%)$ & \multicolumn{2}{c}{ KONSUMSI RIIL (\%) } \\
\cline { 2 - 5 } & SR & LR & SR & LR \\
\hline Rumahtangga Bawah & 2,23 & 6,40 & 2,29 & 6,62 \\
Rumahtangga Atas & 0,66 & 4,76 & 0,27 & 4,50 \\
\hline
\end{tabular}

Keterangan :

$\mathrm{SR}=$ jangka pendek (short-run)

$\mathrm{LR}=$ jangka panjang (long-run)

\subsubsection{Kenaikan TDL diikuti Penurunan PPN di Seluruh Sektor}

Pada jangka pendek maupun jangka panjang, dampak kenaikan TDL yang diikuti penurunan PPN sebesar 1 persen di seluruh sektor (skenario 4) mampu meningkatkan PDB riilnya. Peningkatan PDB riil tersebut disebabkan oleh peningkatan output hampir disemua sektor ekonomi akibat adanya penurunan PPN yang mampu menekan biaya produksi akibat kenaikan TDL. Pada jangka pendek kenaikan PDB riil sebesar 1,43 persen didorong oleh lonjakan ekspor riil dan peningkatan total konsumsi rumahtangga masing-masing sebesar 1,46 persen dan 1,86 persen. Pada jangka panjang peningkatan PDB riil mencapai 10,98 persen karena lonjakan volume ekspor hingga 16,06 persen dan kenaikan total konsumsi rumahtangga yang melonjak hingga 11,81 persen. Tingginya kenaikan PDB riil akibat kebijakan penurunan PPN pada jangka panjang mengindikasikan bahwa kebijakan tersebut akan direspon lebih baik dimasa depan.

Kenaikan TDL yang diikuti penurunan PPN pada seluruh sektor berdampak pada peningkatan permintaan tenaga kerja sebesar 4,58 persen pada jangka pendek. Pada sektor industri, kenaikan TDL yang diikuti penurunan PPN sebesar 1 persen diseluruh sektor mengakibatkan peningkatan permintaan tenaga kerja yang berkisar antara 0,02 persen (industri semen) sampai 14,87 persen (industri makanan, minuman dan tembakau) pada jangka pendek. Sedangkan Industri logam dasar besi, baja dan bukan besi merespon kebijakan penurunan PPN tersebut dengan peningkatan penyerapan tenaga kerja jauh lebih besar di jangka panjang. Hal ini terjadi karena sektor tersebut padat modal sehingga perlu penyesuaian modal untuk meningkatkan outputnya. Selain itu dampak inflasi akibat kenaikan TDL pada jangka pendek dapat diminimisasi bahkan pada jangka panjang indeks harga konsumennya menurun sebesar 0,47 persen. 
Tabel 10. Dampak Kenaikan TDL diikuti Penurunan PPN di Seluruh Sektor Terhadap Peubah-peubah Ekonomi Makro di Indonesia

\begin{tabular}{lcc}
\hline \multicolumn{1}{c}{ DESKRIPSI } & \multicolumn{2}{c}{ DAMPAK (\%) } \\
\cline { 2 - 3 } Peubah Ekonomi Makro & $\mathrm{SR}$ & $\mathrm{LR}$ \\
\hline Neraca perdagangan/PDB (delB) & 0,00 & 0,03 \\
Tenaga kerja (employ) & 4,58 & 0,00 \\
Indeks deflator PDB sisi & $-0,18$ & $-0,62$ \\
pengeluaran (pOgdpexp) & & \\
Upah nominal (p1lab) & 0,07 & 4,97 \\
Indeks harga investasi (p2tot) & $-0,58$ & $-0,56$ \\
Indeks harga konsumen (p3tot) & 0,07 & $-0,47$ \\
Indeks harga ekspor (p4tot) & 0,02 & $-0,71$ \\
Upah riil (realwage) & 0,00 & 5,47 \\
Indeks volume impor (xOcif_c) & 0,54 & 3,20 \\
PDB riil penggunaan (xOgdpexp) & 1,43 & 10,98 \\
Konsumsi RT (x3tot) & 1,86 & 11,81 \\
Indeks volume ekspor (x4tot) & 1,46 & 16,06 \\
\hline
\end{tabular}

Keterangan :

$\mathrm{SR}=$ jangka pendek (short-run)

$\mathrm{LR}=$ jangka panjang (long-run)

Kebijakan penurunan PPN pada seluruh sektor diirespon kedua kelompok rumahtangga dengan peningkatan konsumsi pada sektor yang mengalami penurunan harga. Pada jangka pendek, total konsumsi rumahtangga bawah meningkat sebesar 2,18 persen sedangkan rumahtangga atas hanya 0,53 persen. Pada jangka panjang, peningkatan total konsumsi rumahtangga bawah dan rumahtangga atas semakin besar masingmasing mencapai 12,46 persen dan 9,86 persen. Peningkatan total konsumsi rumahtangga yang sangat besar ini didorong adanya kenaikan upah riil hingga 5,47 persen di jangka panjang.

Tabel 11. Dampak Kenaikan TDL diikuti Penurunan PPN di Seluruh Sektor terhadap Total Pendapatan dan Konsumsi Rumahtangga.

\begin{tabular}{ccccc}
\hline \multirow{2}{*}{ KELOMPOK } & \multicolumn{2}{c}{ TOTAL PENDAPATAN $(\%)$} & \multicolumn{2}{c}{ KONSUMSI RIIL (\%) } \\
\cline { 2 - 5 } & \multicolumn{2}{c}{ SR } & LR & \multicolumn{2}{c}{ SR } & \multicolumn{1}{c}{ LR } \\
\hline Rumahtangga Bawah & 2,18 & 11,54 & 2,17 & 12,14 \\
Rumahtangga Atas & 0,53 & 9,75 & 0,05 & 9,86 \\
\hline
\end{tabular}

Keterangan :

$\mathrm{SR}=$ jangka pendek (short-run)

$\mathrm{LR}=$ jangka panjang (long-run) 


\section{Kesimpulan dan Saran}

\subsection{Kesimpulan}

Kebijakan kenaikan TDL yang dilakukan pemerintah baik dalam jangka pendek maupun jangka panjang berdampak negatif terhadap kinerja ekonomi makro dan sektoral di Indonesia. Secara makro, kebijakan tersebut akan menyebabkan terjadinya penurunan PDB riil, penyerapan tenaga kerja agregat, total konsumsi rumahtangga, dan investasi sekaligus menyebabkan inflasi. Secara sektoral, kebijakan kenaikan TDL juga berdampak negatif terhadap output, tenaga kerja, konsumsi rumahtangga dan tingkat harga.

Kebijakan kenaikan TDL juga berdampak pada penurunan total konsumsi rumahtangga atas maupun rumahtangga bawah, dimana penurunan rumahtangga atas jauh lebih besar daripada rumahtangga bawah.

Dampak kenaikan TDL akan lebih dirasakan dalam jangka panjang dibanding jangka pendek. Ini dikarenakan pada jangka panjang kebijakan yang dilakukan pemerintah tersebut akan menyebabkan terjadinya penurunan investasi yang lebih besar, sehingga menghambat perkembangan sektor ekonomi.

Peningkatan efisiensi di sektor listrik sebesar 10 persen mampu menurunkan biaya produksi listrik sehingga dengan kebijakan tersebut tidak perlu adanya kebijakan kenaikan TDL. Peningkatan efisiensi di sektor listrik juga berpengaruh positif terhadap kinerja ekonomi makro maupun sektoral. Hal itu terlihat dari meningkatnya PDB riil, total konsumsi rumahtangga dan penyerapan tenaga kerja baik pada jangka pendek maupun jangka panjang.

Kebijakan kenaikan TDL jika diikuti peningkatan efisiensi sebesar 1 persen di seluruh sektor ekonomi pada jangka pendek berdampak positif pada peningkatan PDB riil, penyerapan tenaga kerja, peningkatan total konsumsi dan ekspor. Kebijakan tersebut masih mendorong inflasi.

Kebijakan kenaikan TDL yang diikuti penurunan PPN sebesar 1 persen pada seluruh sektor berdampak positif terhadap kinerja ekonomi makro maupun sektoral di Indonesia. Secara sektoral dampak positif penurunan PPN tersebut mampu menekan harga dan meningkatkan output sektoral walaupun masih menyebabkan inflasi. Meningkatnya output sektoral mendorong peningkatan penyerapan tenaga kerja yang cukup besar sehingga kebijakan ini sangat efektif untuk mengatasi pengangguran di Indonesia.

\subsection{Saran}

Berdasarkan hasil penelitian maka beberapa saran ke depan antara lain: (1) sektor listrik sebaiknya meningkatkan efisiensi sebesar 10 persen karena mampu menurunkan harga listrik hingga 24,97 persen sehingga pemerintah tidak perlu menetapkan kebijakan kenaikan TDL, (2) kenaikan TDL yang berdampak meningkatnya biaya produksi pada sektor ekonomi hendaknya diimbangi dengan peningkatan efisiensi oleh produsen sehingga output yang dihasilkan bisa bersaing harga baik dipasar domestik maupun luar negeri (3) Pemerintah perlu membuat kebijakan menurunkan PPN saat perekonomian melemah karena dampak kenaikan TDL, sehingga industri tetap mampu berproduksi dengan harga output sesuai daya beli masyarakat.

\section{Daftar Pustaka}

[BPS] Badan Pusat Statistik. 2010. Tabel Input Output Indonesia Tahun 2008 Jakarta: BPS

[BPS] Badan Pusat Statistik. 2010. Sistem Neraca Sosial Ekonomi Indonesia Tahun 2008 Jakarta: BPS 
[BPS] Badan Pusat Statistik. 2005. Tabel Input Output UKM Tahun 2003. Jakarta : BPS

Dixon, PB, Parmenter BR, Powell A, dan Wilcoxen PJ. 1992. Notes and Problems in Applied General Equilibrium Economics. Amsterdam: North Holland.

Floriasari. 2009. Dampak Peningkatan Subsidi Listrik terhadap Distribusi Pendapatan Rumahtangga. [Skripsi]. Jakarta : Sekolah Tinggi Ilmu Statistik.

Hayati F. 2008. Permintaan Konsumen Terhadap Listrik Pada Rumahtangga. [Skripsi]. Yogyakarta : Universitas Islam Indonesia.

Horridge M. 2001. Minimal: A Simplified general Equilibrium Model. Australia: Centre of Policy Studies and Impact Project, Monash University.

Komaidi dan Rakhmanto P. 2010. Mengukur Dampak Ekonomi Kenaikan TDL 2010. Konferensi Pers ReforMiner Institute. Jakarta

Makmun dan Abdurrahman. 2003. Dampak Kenaikan Tarif Dasar Listrik Terhadap Konsumsi Listrik dan Pendapatan Masyarakat. Jurnal Keuangan dan Moneter, Volume 6 Nomor 2.63-83.

Oktaviani R. 2000. The Impact of APEC Trade Liberalization on Indonesian Economy and Its Agricultural Sektor [Disertasi]. The Sidney University.

2008. Model Ekonomi Keseimbangan Umum: Teori dan Aplikasinya di Indonesia. Bogor: FEM IPB.

Praptono. 2006. TDL, Titik Awal Efisiensi Nasional Majalah Warta Anggaran, Direktorat Jenderal Anggaran. Depkeu Edisi 5 Tahun 2006.

Punt C. 2005. A Computable General Equilibrium(CGE) Analysis of the
Impact of an Oil Price Increase in South Africa. Elsenburg Working Paper 2005: 1

Purwoko. 2006. Analisis Peran Subsidi bagi Industri dan Masyarakat Pengguna Listrik. Jurnal Keuangan dan Moneter, Volume 6 Nomor 2 .44-62

Riadi, M. 2010. Dampak Kebijakan Stimulus Fiskal Bidang Infrastruktur Padatkarya terhadap Kinerja Ekonomi Makro dan Ekonomi Sektoral di Indonesia. [tesis]. Bogor: Sekolah Pascasarjana, Institut Pertanian Bogor.

Sahara. 2003. Dampak Kenaikan Harga Bahan Bakar Minyak, Tarif Dasar Listrik, Tarif Telephon dan Penyaluran Dana Kompensasi terhadap Ekonomi Makro dan Sektoral di Indonesia [tesis]. Bogor: Sekolah Pascasarjana, Institut Pertanian Bogor.

dan R. Oktaviani. 2008. Penggunaan Program GEMPACK untuk Membangun Data Dasar dan Simulasi Model CGE. Bogor : Institut Pertanian Bogor

Sugema, I. 2005. Dampak Kenaikan Harga BBM dan Effektivitas Program Kompensasi. Jakarta: Tim INDEF dan FEM IPB.

Tribuana N. 2000. Laporan Akhir Pengkajian Tekno Ekonomi ketenaga listrikan Bidang Harga Jual Tenaga listrik. Proyek Induk Sarana Pengujian dan Penunjang Ketenagalistrikan. Jakarta : Direktorat Jenderal Listrik dan Pengembangan Energi

Wittwer G. 1999. WAYANG: A General Equilibrium Model Adapted for Indonesian Economy. Centre for International Economic Studies, School of EcAdelaide. 